intensive care unit. Our results confirm that it provides satisfactory sedation in patients requiring mechanical ventilation with a range of severity of illness as determined by their APACHE II scores. The degree of sedation with isoflurane was easily and rapidly controlled by changing the inspired isoflurane concentration delivered to the patient. The effective dose of isoflurane for sedating ventilated patients in the intensive care unit was confined to a narrow range $(0 \cdot 1-0 \cdot 4 \%$ concentration), whereas the requirement for midazolam showed considerable variability between patients $(0 \cdot 014-0 \cdot 140 \mathrm{mg} / \mathrm{kg} / \mathrm{h})$. Patients sedated with isoflurane were often tranquil and cooperative, whereas those sedated with midazolam were often confused and disruptive, requiring increasingly higher infusion rates that resulted in oversedation. Provided that patients were not hypovolaemic, isoflurane or midazolam sedation did not have deleterious effects on haemodynamic stability.

In conclusion, isoflurane in subanaesthetic concentrations $(0 \cdot 1-0 \cdot 6 \%)$ provides a useful alternative technique for sedation of ventilated patients in the intensive care unit. It has many advantages over conventional intravenous sedative agents. The quality of sedation and speed of recovery from sedation are significantly better with isoflurane than midazolam. Further studies are required to assess the side effects of prolonged isoflurane sedation.

We thank our medical and surgical consultant colleagues for permission to study their patients on the intensive care unit; the nursing and medical staff of the intensive care unit, Bristol Royal Infirmary, for their help and cooperation with the study; M Shapland, University of Bristol Computer Centre, for help with design of the database and computing; and A Dennis, statistician, University of Bristol, for statistical advice.
1 Kong KL, Willatts SM. Isoflurane for sedation of ventilated patients in intensive care. Clin Pharmacol Ther 1988;43:142.

2 Knaus WA, Draper EA, Wagner DP, Zimmerman JE. APACHE II: a severity of disease classification system. Crit Care Med 1985;13:818-29.

3 Ramsay MAE, Savege TM, Simpson BRJ, Goodwin R. Controlled sedation with alphaxalone-alphadolone. $\mathrm{Br}$ Med f 1974;ii:656-9.

4 Bion JF, Ledingham IM. Sedation in intensive care: a postal survey. Intensive Care Med 1987;13:215-6.

5 Tubaro E, Borelli G, Croce C, Cavallo G, Santiangeli C. Effect of morphine on resistance to infection. I Infect Dis 1983;148:656-66.

6 Macnab MSP, Macrae DJ, Guy E, Grant IS, Feely J. Profound reduction in morphine clearance and liver blood flow in shock. Intensive Care Med 1986;12:366-9.

7 Osborne RJ, Joel SP, Slevin ML. Morphine intoxication in renal failure: the role of morphine-6-glucuronide. Br Med 7 1986;292:1548-9.

8 Grummit RM, Goat VA. Intracranial pressure after phenoperidine. Anaesthesia 1984;39:565-7.

9 Bingham RM, Hinds CJ. Influence of bolus doses of phenoperidine on intracranial pressure and systemic arterial pressure in traumatic coma. Br F Anaesth 1987;59:592-5.

10 Cohen AT, Kelly DR. Assessment of alfentanil by intravenous infusion as long-term sedation in intensive care. Anaesthesia 1987;42:545-8.

11 Sinclair ME, Sear JW, Summerfield RJ, Fisher A. Alfentanil infusions on the intensive therapy unit. Intensive Care Med 1988;14:55-9.

12 Yate PM, Thomas D, Short SM, Sebel PS, Morton J. Comparison of infusions of alfentanil or pethidine for sedation of ventilated patients on the ITU. of alfentanil or pethidine for

13 McDonnell TE, Bartowski RR, Kahn C. Evidence for polymorphic oxidation of alfentanil in man. Anesthesiology 1984;61:A284.

14 Harper KW, Collier PS, Dundee JW, Elliott P, Halliday NJ, Lowry KG. Age and nature of operation influence the pharmacokinetics of midazolam. and nature of operation influ

15 Shelly MP, Mendel L, Park GR. Failure of critically ill patients to metabolise midazolam. Anaesthesia 1987;42:619-26.

16 Dundee JW, Collier PS, Carlisle RJT, Harper KW. Prolonged midazolam elimination half-life. Br f Clin Pharmacol 1986;21:425-9.

17 Geller E, Halpern P, Leykin Y, Rudick V, Sorkine P. Midazolam infusion and benzodiazepine antagonist for sedation in ICU: a preliminary report. Anesthesiology 1986;65:A65.

18 Chiolero RL, Ravussin P, Anderes JP, Ledermann P, de Tribolet N. The effects of midazolam reversal by RO 15-1788 on cerebral perfusion pressure in patients with severe head injury. Intensive Care Med 1988;14:196-200.

19 Newman LH, McDonald JC, Wallace PGM, Ledingham IM. Propofol infusion for sedation in intensive care. Anaesthesia 1987;42:929-37.

20 Grounds RM, Lalor JM, Lumley J, Royston D, Morgan M. Propofol infusion for sedation in the intensive care unit: preliminary report. Br Med $\mathcal{J}$ for sedation in

21 Prys-Roberts C, Corbett JL, Kerr JH, Smith AC, Spalding JMK. Treatment of sympathetic overactivity in tetanus. Lancet 1969;i:542-6.
Medical Research Council Common Cold Unit, Harvard Hospital, Salisbury SP2 8BW David Tyrrell, MD, director Ian Barrow, MD, clinician

Adelaide Health Centre, Andover, Hampshire James Arthur, MRCS, general practitioner

Correspondence to: Dr Tyrrell.

BrMed f 1989;298:1280-3

\title{
Local hyperthermia benefits natural and experimental common colds
}

David Tyrrell, Ian Barrow, James Arthur

\section{Abstract}

Objective-To determine whether inhaling fully humidified air at $43^{\circ} \mathrm{C}$ gave more benefit to cold sufferers than inhaling air at $30^{\circ} \mathrm{C}$

Design-Randomised double blind trial.

Setting-General practice and the common cold research unit.

Subjects-87 Unselected patients with typical acute nasal and upper respiratory symptoms (general practice study), and 84 volunteers aged 18-50 without a history of chronic or allergic diseases.

Interventions - Subjects breathed from apparatus delivering 40 litres of room air heated to $43^{\circ} \mathrm{C}$ or $30^{\circ} \mathrm{C}$ and fully humidified (relative humidity $100 \%$ ) per minute.

End point-Reduction in severity of disease.

Measurements and main results-Patients recorded their symptoms (general practice study) and observers recorded symptoms and signs, weight of nasal secretions, isolation of virus, and antibody responses in volunteers. Patients treated for 20 minutes at $43^{\circ} \mathrm{C}$ had in the succeeding days roughly half the score for symptoms of those treated at $30^{\circ} \mathrm{C}$. Volunteers treated for 30 minutes on three occasions when they were starting a cold showed a $43 \%$ reduction in symptoms. Treatment of volunteers for $\mathbf{2 0}$ minutes at the onset of the cold and for 10 minutes on succeeding days showed no difference between $43^{\circ} \mathrm{C}$ and $30^{\circ} \mathrm{C}$.
Conclusions-Nasal hyperthermia can improve the course of a common cold and also give immediate relief of symptoms.

\section{Introduction}

Inhaling warm, damp air is widely accepted to relieve the symptoms of colds and other acute respiratory infections, and, indeed, inhaling humidified air is part of the management of lower respiratory disease in some paediatric centres. Greater benefit, however, may be obtained by administering hot humidified air so that the temperature of the nasal mucosa is raised. Equipment to do this has undergone preliminary trials (A Beacham, J Levenstein, unpublished), which suggested that inhalations that raised the temperature of the nasal mucosa to $43^{\circ} \mathrm{C}$ for 20 minutes led to a rapid resolution of common colds.

Lwoff suggested that raising the mucosal temperature to $43^{\circ} \mathrm{C}$ for three periods of 30 minutes at intervals of two hours would block the replication of rhinoviruses and so abort common colds. ${ }^{1}$ An apparatus to do this (the Rhinotherm) was developed in Israel, and it was claimed that $80 \%$ of subjects who used the apparatus in the early stages of a cold were better the next day. ${ }^{2}$ The control groups in this trial were not apparently balanced with the experimental group, and the control apparatus would have been readily distinguished from the active apparatus as it 
delivered only $5 \%$ of the air of the active apparatus. An effective double blind design is essential in trials that depend heavily on the patients' reports of symptoms. We investigated the use of hot humidified air with an apparatus that was easy to use and delivered 40 litres of fully saturated air at either $43^{\circ} \mathrm{C}$ or $30^{\circ} \mathrm{C}$ per minute.

\section{Subjects and methods}

The machines, which were unlabelled, were placed on a table, and the patient sat on a chair and breathed through a vented anaesthetic mask. Some machines were set at $43^{\circ} \mathrm{C}$ and others at $30^{\circ} \mathrm{C}$; the mean temperatures of the nasal mucosa were $43^{\circ} \mathrm{C}$ and $33^{\circ} \mathrm{C}$, respectively. Both machines gave the sensation of breathing warm, moist air. Other aspects of the administration and assessment were carefully double blinded.

General practice study-Patients came to the Adelaide Centre, Andover, in response to circulars and advertisements, and one of us (JA) took a simple history, asking particularly for any serious underlying disease, chronic or recurrent respiratory infections, respiratory allergies such as hay fever and asthma, and other allergies. Patients whom he thought had true common colds were admitted to the trial. The diagnosis was made on the basis of a short history and presence of typical symptoms, such as runny nose, stuffiness, sore throat, cough, and headache. All the subjects were adults and signed the consent section of a record form, and the full protocol of the trial was approved by Winchester ethical committee. Patients were allocated to treatment by reference to a list of random numbers and inhaled on one occasion for 20 minutes under observation. They were seen immediately after treatment by a doctor, who asked about adverse effects and recorded whether their symptoms were the same, better, or worse. They recorded the severity of their symptoms daily for the next five days on a form with a four point scale (0 to 3 ). These forms were returned and used for the analysis.

Volunteer study-Volunteers were recruited to the common cold unit in Salisbury, housed in isolation, and observed as previously described. ${ }^{3}$ The experiment was approved by Harrow district ethical committee. After two days' quarantine they were inoculated twice with intranasal drops containing about 100 times the median tissue culture dose of human rhinovirus type 14. Those volunteers who developed early signs of colds - that is, who used at least four paper handkerchiefs more than their baseline rate and developed one other symptom of a cold-were entered into the trial and allocated at random to receive treatment at $43^{\circ} \mathrm{C}$ or $30^{\circ} \mathrm{C}$. They received three treatments of 30 minutes each with one and a half hours between them. Any immediate change in symptoms was recorded as before, and thereafter their total

TABLE I-Characteristics of patients with colds randomised into general practice study for treatment with warmed air

\begin{tabular}{lcc}
\hline & $\begin{array}{c}\text { Air at } 43^{\circ} \mathrm{C} \\
(\mathbf{n}=45)\end{array}$ & $\begin{array}{c}\text { Air at } 30^{\circ} \mathrm{C} \\
(\mathbf{n}=42)\end{array}$ \\
\hline Men & 23 & 17 \\
Women & 22 & 25 \\
History of other conditions $^{\star}$ & 11 & 18 \\
Duration of symptoms before treatment (days): & & \\
$1-2$ & 21 & 21 \\
$3-4$ & 16 & 15 \\
$\geqslant 5$ & 7 & 4 \\
No of symptoms: & 1 & 7 \\
5 & 5 & 17 \\
4 & 16 & 8 \\
3 & 20 & 7 \\
2 & 3 & 3 \\
1 & $2 \cdot 6$ & $3 \cdot 4$ \\
Mean No of symptoms & & \\
\hline
\end{tabular}

* Such as hay fever or sinusitis.
TABLE II - Immediate effect of 20 minutes of treatment with warmed air on symptoms as reported by volunteers (first trial)

\begin{tabular}{cccc}
\hline & \multicolumn{3}{c}{ Rating of stuffy nose } \\
\cline { 2 - 4 } Temperature of air & Worse & Same & Better \\
\hline $30^{\circ} \mathrm{C}(\mathrm{n}=39)$ & 3 & 20 & $16(41 \%)$ \\
$43^{\circ} \mathrm{C}(\mathrm{n}=45)$ & 3 & 20 & $22(49 \%)$ \\
\hline
\end{tabular}

* Similar results were seen for sore throat, cough, headache, and runny nose.

symptom score and the weight of nasal secretions were recorded by standard methods. Nasal washings were collected each day and tested for the virus. Neutralising antibody was also measured in serum samples collected on arrival and about three weeks later.

Statistical analysis-Rank two way analysis of variance $^{4}$ was used to analyse the results of each trial and was performed on a microcomputer with a program from the statistical package for personal computers ( $\mathbf{P}$ Royston, Clinical Research Centre, Northwick Park Hospital, Harrow, Middlesex). This included a facility for "blocking" data into groups according to the values of a third variable-for example, serum antibody titre or initial clinical score.

\section{Results}

\section{GENERAL PRACTICE STUDY}

Ninety six subjects were enrolled in the general practice trial, from whom 87 satisfactory records were obtained. The two groups, treated with moist air at $30^{\circ} \mathrm{C}$ and $43^{\circ} \mathrm{C}$, were similar in size, ratio of sexes, other clinical conditions, and duration of colds, but those subsequently treated at $30^{\circ} \mathrm{C}$ had significantly more symptoms on presentation (table I). Immediately after treatment $22(49 \%)$ of those given air at $43^{\circ} \mathrm{C}$ and $16(41 \%)$ of those given air at $30^{\circ} \mathrm{C}$ reported an improvement in nasal stuffiness (table II); there were similar small differences in the response of other symptoms to the two treatments. During the subsequent days the mean symptom scores were substantially lower in the group given air at $43^{\circ} \mathrm{C}$, the mean total scores being $9 \cdot 3$ and $25 \cdot 9$, respectively.

As the group given air at $30^{\circ} \mathrm{C}$ had had significantly more symptoms than the group given air at $43^{\circ} \mathrm{C}$ on admission to the trial the significance and size of the beneficial effect might have been overestimated by a simple analysis. We therefore performed a rank analysis of variance. This gave a valid statistic, although the symptom scores were not normally distributed, and we also "blocked" for the scores before treatment. The differences were highly significant (fig 1). We allowed approximately for the differences in numbers of symptoms before treatment by "correcting" the total score $(25 \cdot 9 \times(2 \cdot 6 / 3 \cdot 4)=19 \cdot 8)$, suggesting that the scores of the treated group were reduced to $47 \%(9 \cdot 3 / 19 \cdot 8)$ of those expected.

The subgroups with only nasal symptoms were analysed separately, and, though the numbers were small, the initial illnesses were comparable. The mean total scores were 12.3 after treatment with air at $30^{\circ} \mathrm{C}$ and 7.7 after treatment at $43^{\circ} \mathrm{C}(\mathrm{p}<0.05)$, representing a reduction of $37 \%$, and the differences in the mean daily scores were also significant (fig 2). We also looked at the day on which no symptoms were recorded, which was assumed to be the end of the cold. On the fourth day of observation $21(47 \%)$ of the group given air at $43^{\circ} \mathrm{C}$ had a symptom score of zero, whereas only 1 (2\%) of the group given air at $30^{\circ} \mathrm{C}$ did.

We concluded that, in spite of the imbalance of the study groups, local hyperthermia for 20 minutes had improved the course of the colds, though the effect was less than that reported earlier. On the other hand, 


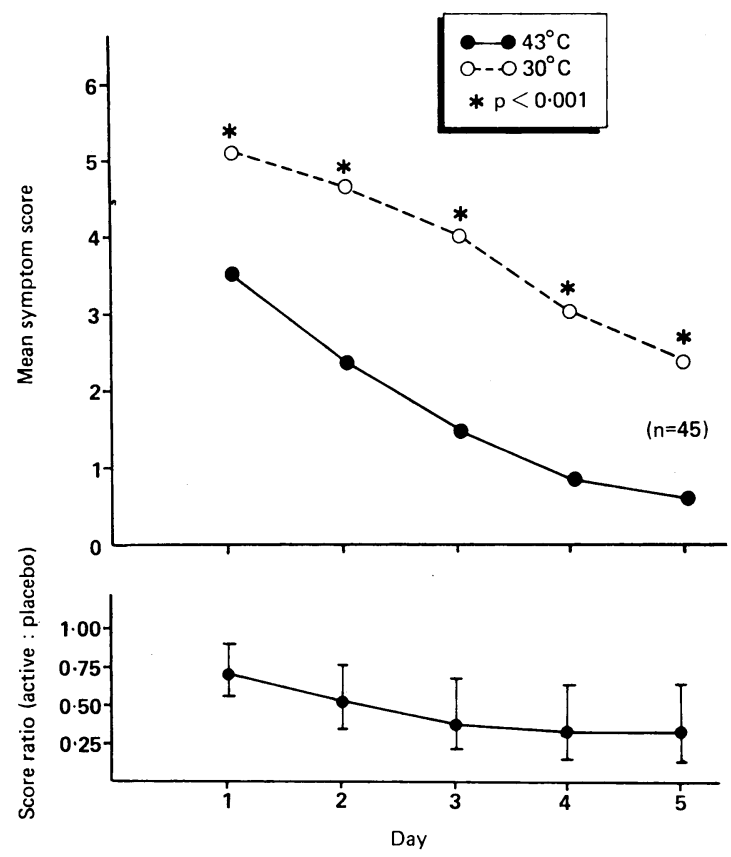

FIG 1-Top: Mean symptom scores for patients with natural colds treated with air at $43^{\circ} \mathrm{C}$ or at $30^{\circ} \mathrm{C}$. Mean duration of colds after treatment at $30^{\circ} \mathrm{C}$ was 4.9 days and at $43^{\circ} \mathrm{C}$ was 3.5 days. Bottom: Daily ratio of symptom scores with test based $95 \%$ confidence intervals ${ }^{6}$

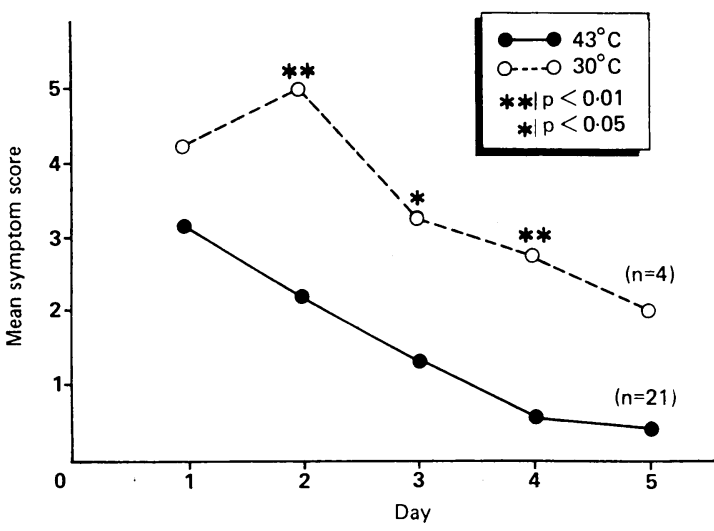

FIG 2-Mean symptom scores for patients who had nasal symptoms only. Mean duration of symptoms after treatment at $30^{\circ} \mathrm{C}$ was $4 \cdot 7$ days and at $43^{\circ} \mathrm{C}$ was 3.0 days

we had treated our subjects less intensively than prescribed by Lwoff and we had not tested whether the treatment had prevented further infection with the virus as he predicted. ${ }^{1}$ Our volunteer study helped to resolve these problems.

\section{VOLUNTEER STUDIES}

In all, 27 of the 75 volunteers inoculated developed colds. For these volunteers there was clearly greater benefit from air at $43^{\circ} \mathrm{C}$ (table III). The difference in the proportions of the groups of volunteers who showed improvement was significant $(61 \%(95 \%$ confidence interval $31 \%$ to $91 \%$ )).

Figure 3 shows the subsequent courses of the colds as indicated by mean total daily symptom scores and the mean weights of daily nasal secretions. The scores of the two groups were similar on the day of treatment and were subsequently reduced by about $20 \%$ in those treated at $43^{\circ} \mathrm{C}$; likewise the weights of secretion were reduced by a maximum of $42 \%$ after two days. By simple rank analysis these differences were not significant; when "blocked" by the initial weight of nasal secretions (allowing for the fact that on entry to the trial some volunteers had worse colds than others), however, they reached significance on several days. The difference in mean total score was significant $(14 v$ $24, \mathrm{p}=0 \cdot 02$, one tail test) as was the difference in mean total weight of secretions ( $26 v 33, \mathrm{p}=0.027)$, these reductions being $43 \%$ and $21 \%$, respectively.

By contrast there were no differences in the proportion of volunteers shedding the virus between the two groups after treatment, although the proportion was lower, though not significantly so, on the day of treatment in the group given air at $43^{\circ} \mathrm{C}$ (fig 3 , bottom). The frequency of antibody response $\left(5 / 14\right.$ at $43^{\circ} \mathrm{C}$ and $7 / 13$ at $30^{\circ} \mathrm{C}$ ) and the mean titres in convalescence $(1 / 3.7 v 1 / 8 \cdot 0)$ were also not significantly different.

Some volunteers mentioned local discomfort in the first few minutes of treatment at $43^{\circ} \mathrm{C}$. Although volunteers were encouraged to report freely and were examined daily, there was no indication of adverse effects from the treatment.

We wanted to establish whether shorter treatments would yield the same results, so a similar study was done with a modified scheme in which volunteers received 20 minutes of treatment on the day of diagnosis and a further 10 minutes each morning until the symptoms resolved or the trial ended. In this case no continued improvement was seen.

\section{Discussion}

The main purpose of these studies was to show impartially whether local hyperthermia benefits colds. We believe that we found evidence for this in two quite different groups of subjects and with different designs of trial. Furthermore, our subjects found the treatment acceptable and the amount of benefit was clinically important.

In our first study (general practice study) we treated naturally acquired colds, most of which had been present for over a day; in the second and third studies (volunteer studies) we treated colds that had been present for only a few hours and caused by a single type of rhinovirus. In the first study we relied on subjective self reporting (though we have evidence that this gives results similar to those obtained by a trained independent observer (S Macintyre, in preparation)). In the second and third we also used a trained doctor and an objective measure of disease - that is, weight of daily nasal secretions. All three trials had weaknesses: in the first randomisation generated groups with disease in which the prevalences of symptoms were different; in the second and third the numbers were small for practical reasons.

In spite of this the trials showed some immediate subjective benefit, and in the second study this was clearly greater with air at $43^{\circ} \mathrm{C}$ than $30^{\circ} \mathrm{C}$. The first two studies showed a clinical advantage for those treated at $43^{\circ} \mathrm{C}$, and this continued for two or three days and was confirmed by our most objective measure. The amount of benefit could not be measured exactly, but symptoms and signs were reduced by up to $40 \%$.

TABLE III-Immediate effect of three 30 minute episodes of treatment on symptoms as reported by volunteers (volunteer study)

\begin{tabular}{lllll}
\hline & \multicolumn{5}{c}{ Rating of symptoms } \\
\cline { 2 - 5 } Treatment & Total & Worse & Same & Better \\
\hline At 30 $0^{\circ}$ : & & & 8 & 5 \\
First episode & 15 & 2 & 9 & 4 \\
Second episode & 15 & 2 & 7 & 5 \\
Third episode & $14^{\star}$ & 2 & 24 & $14(32 \%)$ \\
\hline Total & 44 & 6 & & \\
\hline At $43^{\circ} \mathrm{C}:$ & & & 2 & 13 \\
$\quad$ First episode & 14 & & & 14 \\
Second episode & 14 & & 3 & $39(93 \%)$ \\
Third episode & 14 & & &
\end{tabular}

${ }^{\star}$ One volunteer refused third episode of treatment. 

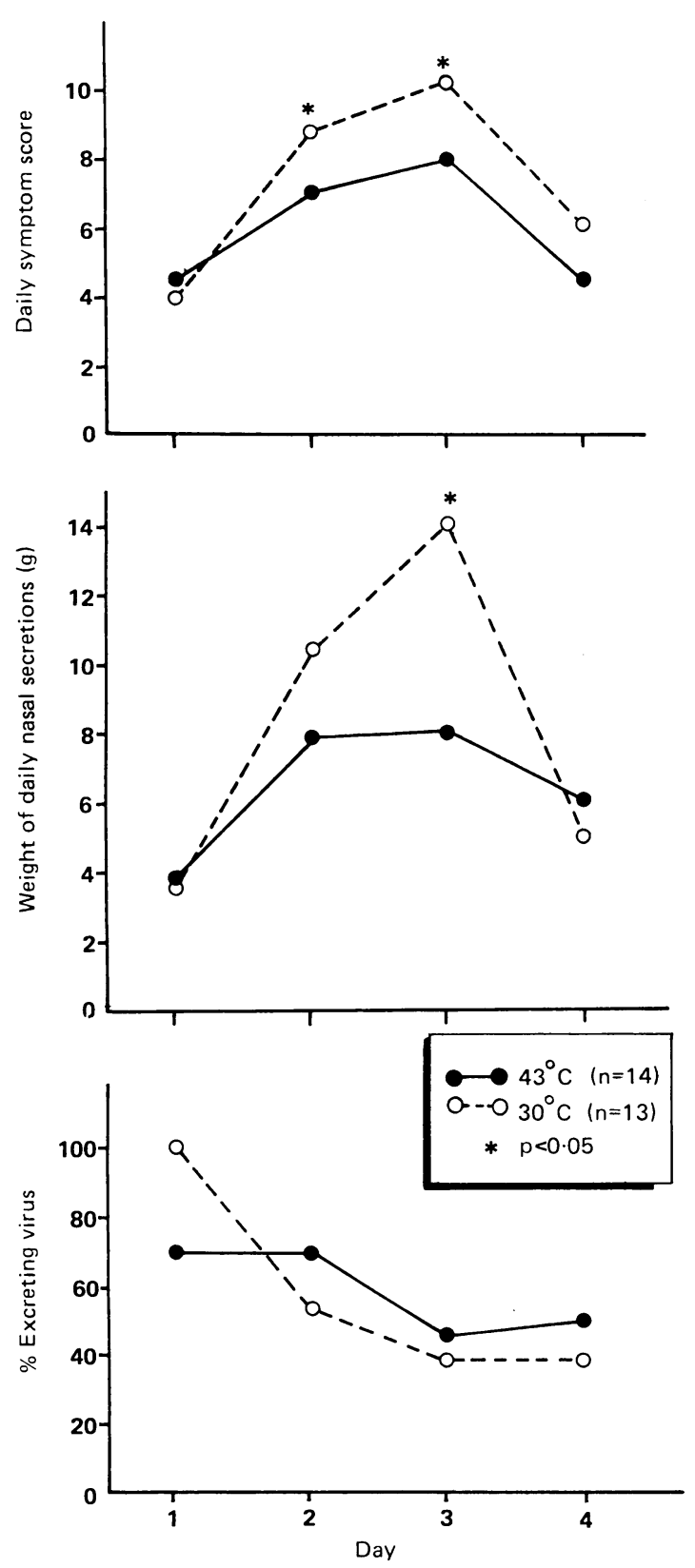

FIG 3-Results of treating volunteers with colds induced by rhinovirus. Symptoms, scores, and weights of secretions on day I refer to the 24 hours in which treatment was started; results of virus isolation on day 1 are given as percentage of those volunteers who received treatment before specimens were collected

Interestingly, a recent independent study in Israel with an improved Rhinotherm apparatus showed that two treatments of 20 minutes given to patients with natural colds reduced another objective variable, nasal airway resistance, by about a third for several days. ${ }^{\text {? }}$ Thus, though we cannot support the claim that $80 \%$ of people with a cold recover by the day after treatment, ${ }^{2}$ we believe that three separate satisfactory trials have now shown that colds are improved for several days after treatment and that this is clinically and statistically significant. There is also immediate relief of symptoms, which may be better if the machine is run at $43^{\circ} \mathrm{C}$ rather than at $30^{\circ} \mathrm{C}$. In clinical practice there would probably also be a useful placebo effect, and some patients would probably start to treat a mild cold that was going to improve anyway. We therefore find plausible the results of an uncontrolled trial which showed that about $80 \%$ of subjects reported that their colds were considerably improved the day after 20 minutes of hyperthermia at $43^{\circ} \mathrm{C}$ (J Levenstein, unpublished data).

Several questions are still unanswered. Evidence suggests that 20 minutes of treatment at $43^{\circ} \mathrm{C}$ of an already developed "natural" cold is beneficial; 20 minutes given early in a mild experimental cold gave no continuing benefit but three treatments of 30 minutes did. Treatments of 10 minutes had little effect. We have no clear evidence that virus replication is halted, as proposed by Lwoff.' There may be a temporary effect, but this seems to disappear and presumably other biological effects are possible. Pyrexia is known to be beneficial in systemic infections, but the details of the mechanisms are obscure. As local hyperthermia at $43^{\circ} \mathrm{C}$ is reported to benefit hay fever ${ }^{\circ}$ possibly it diminishes inflammatory processes or other reflexes or immunological responses. In laboratory models hyperthermia in vitro or in vivo turns on heat shock genes in a wide range of cells, including lymphocytes, and can alter cell behaviour-for instance, it can prevent degranulation of mast cells and induce production of interferon. ${ }^{9.12}$ The regulation and expression of the heat shock genes is, however, complex. ${ }^{13}$ For further clinical evaluation a plausible hypothesis of the mode of action would be valuable and more research on the biological effects of local hyperthermia is justified.

Prolonged respiratory hyperthermia has been used to raise the body core temperature after accidental and experimental immersion in cold water and has been free of unwanted effects ${ }^{5}$ ( $\mathrm{J} \mathrm{S} \mathrm{Hayward,} \mathrm{personal}$ communication). We did not observe any adverse effects in the subjects taking part in these controlled studies or in others treated under uncontrolled conditions. Nevertheless, a watch should be kept for reactions, perhaps in the few patients who are sensitive. Also, some people may derive more immediate benefit than others. These uncontrolled observations have also suggested benefit in conditions such as asthma and chronic sinusitis so controlled studies are needed on these indications too. Lwoff (personal communication) believes that more dramatic results are obtained if air is insufflated into the nose rather than breathed in from a mask; this idea is also worth further study.

We thank Dr P G Higgins for help in the trials at Salisbury; $J$ Dunning and A Dalton for help in the clinical assessment; $C$ Dearden and $M$ Forsyth for laboratory work; Gary Astill for help with equipment; $M$ Sergeant and $\mathrm{K}$ Callow for statistical analysis; and the volunteers for their cooperation. The apparatus was supplied by A Beacham.

1 Lwoff A. Death and transfiguration of a problem. Bacteriological Review 1969;33:390-403.

2 Yerushalmi A, Lwoff A. Traitement du coryza infectieux et des rhinites persistantes allergiques par la thermothérapie. Comptes Rendus de l'Academi des Sciences de Paris 1980;291:957-9.

3 Beare AS, Reed SR. The study of antiviral compounds in volunteers. In: Oxford JS, ed. Chemoprophylaxis and virus infections of the respiratory tract. Vol 2. Cleveland, Ohio: CRC Press, 1977:27-56.

4 Meddis R. Unified analysis of variance by ranks. British fournal of Mathematical and Statistical Psychology 1980;33:84-98

5 Hayward JS, Eckerson JD, Kemna D. Thermal and cardiovascular changes during three methods of resuscitation from mild hypothermia. Resuscitation 1984;11:21-33.

6 Breslow NE, Day NE. Statistical methods in cancer research - the analysis of case control studies. Lyons: International Agency for Research on Cancer. 1980:141.

7 Ophir D, Elad Y. Effects of steam inhalation on nasal patency and nasal symptoms in patients with the common cold. Am $\mathcal{F}$ Otolaryngol 1987;3: $149-53$

8 Yerushalmi A, Karman S, Lwoff A. Treatment of perennial allergic rhinitis by local hyperthermia. Proc Natl Acad Sci USA 1982;79:4766-9.

9 Morimoto R, Fodor E. Cell-specific expression of heat shock proteins in chicken reticulocytes. f Cell Biol 1984;99:1316-23.

10 Dinarello CA, Dempsey RA, Allegretta $M$, et al. Inhibitory effects of elevated temperature on human cytokine production and natural killer activity. Cancer Res 1986;46:6236-41.

11 Downing JF, Taylor MW, Wei K-M, Elizondo RS. In vitro hyperthermia enhances plasma antiviral activity and stimulates the increased synthesis of interferon- $\gamma$. F Interferon Res 1987;7:185-93.

12 Chevance $L G$, Ohayon $\mathrm{H}$. Blocage par la chaleur de la dégranulation de mastocytes de la muqueuse nasale du Cobaye. Comptes Rendus de l'Academie des Sciences Paris 1983;296:499-500.

13 Neidhardt FC, Van Bogelen RA, Vaughn V. The genetics and regulation of heat-shock proteins. American Reviews of Genetics 1984;18:295-329.

(Accepted 9 March 1989)



